\title{
ОСНОВНІ ВЕКТОРИ Й АГЕНТИ СОЦІАЛЬНО-ПОЛІТИЧНОЇ МОБІЛІЗАЦІЇ СІЛЬСЬКОГО ЖІНОЦТВА ВОЛИНІ У ПЕРШ РОКИ СТАНОВЛЕННЯ РАДЯНСЬКОЇ ВЛАДИ
}

\author{
Галина Стародубець \\ Житомирський державний університет імені Івана Франка (Житомир, Україна) \\ e-mail: starodubec@gmail.com \\ ORCID: https://orcid.org/0000-0003-2005-771X
}

\begin{abstract}
Основна мета статті полягає у тому, щоб на прикладі волинського регіону розкрити детермінанти політичної та соціальної мобілізації селянок у період першого десятиріччя становлення радянської влади. Визначено, що основним агентом впливу на процес організації жіночого руху та формування його змісту і форм виступала більшовицька партія. Зазначено, що емансипаційна політика більшовиків грунтувалася на константі невіддільності жіночого руху від загально пролетарського.
\end{abstract}

Ключові слова: більшовики, жінвідділи, радянська влада, класові вороги, жінки, селя$н \kappa и$

Революційні потрясіння першої чверті XX ст. призвели не тільки до територіальних перекроювань карти Європи та світу, але й тектонічних зрушень у свідомості людей. Це був час зародження та творення нових суспільно-політичних ідей, зміни ціннісних установок, переформатування традиційних відносин усередині динамічно змінюваного соціуму. Одним із найбільш яскравих індикаторів цього процесу стала активізація феміністичного руху в напрямку розширення соціальнополітичних прав і свобод жінки.

Жовтневий переворот 1917 року в Російській імперії детермінував формування більшовицькою партією нових стандартів гендерної політики радянської держави. Їх впровадження відбувалося паралельно з процесом радянізації територій колишньої імперії, який мав як спільні, так і відмінні риси, що тією чи іншою мірою проявлялися в окремих регіонах.

Тема створення та діяльності жіночих організацій у період становлення більшовицької влади у 1920-х роках в останні десятиліття стала предметом дослідження низки вітчизняних i зарубіжних вчених. Так, російські науковці С. Айвазова ${ }^{1}$, Н. Пушкарьова², С. Батуренко ${ }^{3}$ розглядають це питання крізь призму аналізу гендерної політики радянської Росії. Їхні погляди збігаються у тому, що «ідеологічною базою формування жіночих пролетарських організацій виявилися основні положення марксистського фемінізму» ${ }^{4}$ Носіями цієї ідеології мета і за-

\footnotetext{
${ }^{1}$ Айвазова С. Русские женщины в лабиринте равноправия (Очерки политической теории и истории. Документальные материалы). Москва: РИК Русанова, 1998.

2 Пушкарева Н. Гендерная система Советской России и судьбы россиянок // Новое литературное обозрение. 2012. № 17. С. 8-23.

3 Батуренко С. Марксистский феминизм: теоретический проект, генезис и опыт практической реализации в XX в. // Вестник Московского Университета. Сер. 18: Социология и политология. 2019. T. 25. C. $11-129$.

4 Ibid. C. 113.
} 
вдання жіночого руху визначалися рамками таких понять як «клас», «класова боротьба», тому, як зазначає Х. Хартман, «їхній фемінізм виявися придавленим їхнім марксизмом»5. Ідейні натхненниці суспільного руху за емансипацію радянської жінки в особі О. Коллонтай, І. Арманд та ін. не відокремлювали його від загально пролетарської боротьби проти «капіталістичного гноблення».

Переважна більшість вчених сходяться на думці, що жіночий рух розгортався під безпосереднім керівництвом більшовицької партії та перебував під постійним контролем з боку держави. Польська дослідниця Н. Ярска називає такі відносини «метафорою про патріархальний, непорушний шлюб, який грунтується на суворій ієрархії та чітко визначених ролях подружжя»6, де лідерські позиції займає комуністична держава. Л. Непіпенко так само вказує, що в перші роки становлення радянської влади встановився «етакратичний гендерний порядок, який сформувався під впливом класово-революційних перетворень»7. 3 позицій визначення моделі стосунків між партією та жіночими організаціями як патерналістської, ця тема під різними ракурсами вивчається О.Лабур ${ }^{8}$, Н. Земзюліною9 , Н. Олійник ${ }^{10}$, О. Вороніною ${ }^{11}$ й ін.

Однак досі поза рамками наукових досліджень залишається тема реалізації гендерної політики більшовицької влади на Волині. Окрім поодиноких наукових розвідок Г. Стародубець ${ }^{12}$, проблема комплексно не висвітлена. На нашу думку, прикордонне розміщення регіону, його національне багатоманіття, переважно аграрний характер господарського укладу не могли не відобразитися на регіональній специфіці жіночого руху, що робить цю тему привабливою для наукових досліджень.

Мета нашої статті полягає у тому, щоб на прикладі волинського регіону розкрити детермінанти політичної та соціальної мобілізації селянок періоду першого десятиріччя становлення радянської влади. Визначити основних агентів впливу на процес організації жіночого руху на селі та формування його змісту і форм.

Практичне втілення основних заходів емансипаційної політики більшовицької влади розпочалося у 1919 р. шляхом «виділення спеціального партійного апарату з агітації та пропаганди серед жінок, який був частиною загальнопартійного апарату, який працював під його безпосереднім керівництвом і контролем»13. Після

\footnotetext{
${ }^{5}$ Хартманн Х. Несчастливый брак марксизма с феминизмом: путь к более прогрессивному союзу. Москва Свободное марксистское издательство, $2016 . \quad$ URL: https://fmbooks.files.wordpress.com/2016/10/hartmann-fin-fin.pdf

6 Jarska N.A. Patriarchal marriage? The women's movement and the communist party in Poland (19451989) // Kwartalnik Historyczny. 2018. Vol. CXXV (Eng.-Language Edition). No. 2. P. 16.

7 Непіпенко Л. Гендерна ідеологія та гендерна політика в радянській політичній культурі України періоду НЕПу // Гілея: науковий вісник. 2019. Вип. 145 (1). С. 119.

8 Лабур 0. Спогади представниць жінвідділів як джерело вивчення радянської політики «жіночого розкріпачення» в Україні 1920-х рр. // Сторінки історії. 2014. Вип. 37. С. 117-127.

9 Земзюліна Н. Ідеологічні та правові механізми формування гендерного паритету в СРСР // Вісник Черкаського університету. Серія Історичні науки. 2013. № 29. С. 132-138.

10 Олійник Н.Ю. Емансипація жінок по-радянськи: особливості та наслідки // Грані. 2015. № 6. C. $144-151$.

11 Вороніна М. Більшовицький емансипаційний експеримент у 1920-х роках. Українські жінки у горнилі модернізації. Харків, 2017. С. 106-130.

12 Стародубець Г. Основні вектори громадсько-політичної діяльності сільського жіноцтва Волині наприкінці 1920-х - на початку 1930-х років // Наукові записки Вінницького державного педагогічного університету ім. М. Коцюбинського. Серія: Історія. 2020. Вип. 32. С. 9-17.

13 Центральний державний архів громадських об'єднань України (далі - ЦДАГО України). Ф.1. Оп. 20. Спр. 348. Арк. 20.
} 
VIII з'їзду РКП(б), у програмі якого зазначалося про створення окремого партійного підрозділу для роботи серед жінок, у Росії, а з 1920-го року - в Україні, розгорнувся процес створення так званих жінвідділів. Їх організаційному становленню передувала активна дискусія у середовищі тогочасного політикуму с приводу доцільності організовувати жіночий рух як частину феміністичного чи робітничого рухів. В одній із резолюцій Х з'їзду РКП(б) «Про роботу партії серед жіночого пролетаріату» категорично зазначається, що «це жодним чином не є фемінізм. Тому що головна мета спеціальної партійної роботи серед жінок є залучення робітниць до загальнопролетарської боротьби, виховання у них класової самосвідомості. Партія проти створення окремих жіночих союзів чи жіночих організацій»14. У такий спосіб більшовики намагалися, з одного боку, спонукати суспільно-політичну активність жінок, розглядаючи їх як значний резерв для розширення своєї соціальної підтримки, з іншого - взяти її під своє безпосереднє керівництво, не випускати з орбіти свого впливу. Емансипаційна політика більшовиків грунтувалася на константі невіддільності жіночого руху від загально пролетарського.

Очільниця жіночого відділу ЦК КП(б)У від лютого 1920 р. Варвара Мойрова, визначаючи основні завдання роботи серед жінок, наголосила, що «на відміну від буржуазних партій, які тісно пов'язані з феміністичним рухом та ідеями класового миру, компартія своє головне завдання бачить у: 1) класовому розшаруванні жіночих мас, загостренні класової свідомості, втягненні робітничих жіночих мас до сфери впливу комуністичної партії; 2) піднятті свідомості цього найбільш відсталого і найбільш експлуатованого трудового пролетаріату; 3) усуненні всякої можливості впливу на них дрібнобуржуазного середовища в особі меншовиків та есерів; 4) втягнені їх у радянське, професійне та партійне будівництво 15 . Як бачимо, більшовики намагалися втиснути жіночий рух у рамки ідеологеми «класової боротьби». Заперечуючи необхідність артикулювання та вирішення специфічно жіночих проблем, більшовицькі лідерки в особі О. Коллонтай, І. Арманд, К. Самойлової, В. Мойрової стверджували, що жінки-пролетарки мають більше спільних інтересів з робітничим пролетаріатом, ніж з буржуазними феміністками.

Олександра Коллонтай у своїх численних працях і публічних виступах щодо становища жінки, виразно акцентувала увагу на принциповій відмінності поглядів так званих марксистських феміністів від ліберальних. Марксисти категорично заперечували можливість комплексного вирішення «жіночого питання» шляхом реставрації капіталістичного суспільства, трансформації Російської імперії з монархічною формою правління у парламентську республіку. Єдиний шлях до реальної емансипації жінки вона та її прихильники вбачали у поваленні існуючого режиму. «Боротьба робітничого класу проти капіталізму, - як слушно зауважує Х. Хартман, - мусила мати пріоритет над конфліктом між чоловіками і жінками. Не можна було допустити, щоб конфлікт між статями перешкоджав класовій солідарності»16. Саме тому вони різко виступали проти тісного співробітництва з жіночими організаціями, які стояли на ліберальних позиціях і не розглядали класову нерівність як основу соціальної ієрархії.

Така ідейно-політична основа формування жінвідділів не сприяла консолідації жіноцтва навколо вирішення питань гендерного порядку. Швидше навпаки, ця

14 ЦДАГО України. Ф. 1. Оп. 20. Спр. 348. Арк. 20.

15 ЦДАГО України. Ф. 1. Оп. 20. Спр. 1557. Арк. 27.

16 Хартманн Х. Несчастливый брак марксизма с феминизмом... С. 15. 
організація пропагувала ідею класового антагонізму, сепарування жіночого соціуму за ознакою соціального походження, майнового цензу, політичних вподобань тощо. Як результат, «1920-ті роки не привели до автоматичної емансипації жінок, які безпосередньо брали участь у побудові соціалізму, - стверджує Клементс Барбара Еванс. - Партійне керівництво визначило набір пріоритетів, які відсунули емансипацію жінок на другий план, рядові члени часто відкрито вороже ставилися до жінвідділів» ${ }^{17}$. Незважаючи на очевидні позитивні зрушення у вирішенні «жіночого питання», зафіксовані на рівні правових документів, по факту в цей період було покладено початок процесу «“перепідпорядкування” жінки від чоловіка до держави», у чому, як слушно зазначає О. Вороніна, «і криється глибинний сенс радянської емансипаційної політики» 18.

Відразу після захоплення більшовиками влади в Україні, започаткований у Росії досвід організації жінвідділів почав реалізовуватися тут у рамках процесу радянізації. «Перший в Україні жінвідділ було створено при Харківському губкомі КП(б)У. А із заснуванням відділу робітниць і селянок при Центральному комітеті КП(б)У в січні 1920 р. розпочалася систематична робота партії серед жінок» ${ }^{19}$, яка, згідно 3 висновками українських науковців, особливо активізувалася «після Всеукраїнської наради комуністок у травні 1920 року»20. Відповідальність за організацію роботи 3 жінками на місцях покладалася на губернські, повітові, волосні жінвідділи при партійних комітетах і «потужний постійний провідник впливу на ці маси в особі безпартійних делегатських зборів»21. Однак, слабка організація праці цих органів, відсутність достатньої кількості фахових співробітників, фінансово-матеріальної підтримки, скептичне ставлення до теми жіночих питань, аж до повного їх ігнорування зі сторони представників місцевої влади, зумовили на початку 1921 р. «хвилю питань про ліквідацію жінвідділів»22.

Такі настрої викликали занепокоєння зі сторони центральних владних органів, зокрема ЦК КП(б)У. Тому було вжито рішучих заходів для їх подолання й активізації роботи регіональних осередків більшовицької партії. Місцеві партійні комітети отримували інструкції та розпорядження щодо оптимізації діяльності жінвідділів і жінделегаток у кожному окремому регіоні України. Зважаючи на історично зумовлену етнічну, соціально-економічну, культурну строкатість українських земель, більшовицько-радянська влада не могла ігнорувати цей чинник у процесі реалізації своєї політики. Тому, залежно від регіональних особливостей, форми та зміст партійної роботи з жінками різнилися.

Загальний зміст роботи жінвідділів грунтувався на класово-пролетарських засадах, визначених програмовими положеннями комуністичної партії більшовиків та артикульованих у численних виступах та працях її провідних ідеологів. Зважаючи на різні категорії жіночого населення, очільниці жінвідділів отримували партійні інструкції щодо змістовного наповнення роботи окремо серед робітниць і селянок.

Попри упереджено зневажливе ставлення до сільської жінки, заходи влади у

\footnotetext{
17 Clements Barbara Evans. Bolshevik Women. New York and Cambridge, England: Cambridge University Press, 1997. P. 211.

18 Воронина О.А. Феминизм и гендерное равенство. Москва: Эдиториал УРСС, 2003. С. 115.

19 Земзюліна Н. Ідеологічні та правові механізми... С. 134.

20 Лабур О. Спогади представниць жінвідділів... С. 120.

${ }^{21}$ ЦДАГО України. Ф. 1. Оп. 20. Спр. 1557. Арк. 27.

22 Ibid. Арк. 27зв.
} 
напрямку їі емансипації свідчать, що «основною післявоєнною тенденцією стала фемінізація сільського господарства»23. У державі, де аграрний сектор займав домінуючі позиції, підтримка українським селом політики комуністичної партії та радянського уряду, мала для них надзвичайно важливе значення у контексті розширення соціальної бази та економічного виживання. Оскільки Волинь - це традиційно аграрний регіон, то важливим питанням порядку денного місцевих комуністів стояло розгортання агітаційно-пропагандистської роботи у середовищі сільського волинського жіноцтва.

Парадоксально, але більшовицька влада у селі зробила ставку на жінку, котра насправді у Російській імперії перебувала в лещатах подвійного гніту - побутового, економічного та політичного, була традиційно політично пасивною. Більше того, представники місцевої партійної та радянської номенклатури часто-густо демонстрували гендерне несприйняття громадсько-політичної активності жінрад, що не сприяло зростанню й так доволі низького їх авторитету серед селянських мас. Тим не менше, державне керівництво твердо стояло на позиціях утілення в життя основних положень гендерної політики, розглядаючи «жінок-селянок провідниками соціальних змін, які мають з'єднати новий режим зі старими традиціями»24.

Координаційним центром діяльності жінвідділів регіону виступав Волинський губернський жіночій відділ (далі - Волгубжінвідділ). До середини весни 1922 р. його очільницею була Данилова, але у зв'язку з ії хворобою робота велася дуже мляво і 28 квітня 1922 р. Бюро Волгубкому прийняло постанову про призначення на посаду керівника Волгубжінвідділу А. Кучук, яка була відряджена сюди на партійну роботу з Донбасу25. Апарат відділу в 1922 р. складався з двох посадовців голови і секретаря та перебував у сфері постійного контролю з боку агітвідділу губернського комітету більшовицької партії (далі - губком). Зважаючи на фактичну відсутність відповідних кадрів на селі, «головні сили зі сторони губкому спрямовувалися на волосні і сільські осередки» 26 , які мали опікуватися питаннями організації жіночого руху серед селянок. Загалом Волинська губерній у той час «мала 40 волосних організаторів, однак заробітну плату отримували тільки 30, що негативно позначалося на якості їхньої роботи» 27.

Варто зазначити, що більшовицька пропаганда традиційно трактувала сільських жінок як апріорі ідеологічно відсталіших і неосвічених, порівняно з робітницями. Тому перед жінвідділами ставилося завдання підняти рівень політичної свідомості селянок, якщо не до «чоловічої планки», то, принаймні, до рівня жінокпролетарок. Як правило «наставниками» жіночої частини сільського населення, виступали вихідці з робітничого класу. Власне, як ми уже зазначали, керівниця Волгубжінвідділу прибула сюди з промислового регіону України - Донбасу. Однією 3 форм ідеологічної роботи серед селянок була їх «жива участь в кампаніях, які проводилися на селі, у зборах по виборах жінделегаток»28.

\footnotetext{
${ }^{23}$ Simonton Deborah. Women workers; working women. The Routledge History of Women in Europe since 1700. London and New York, 2007. P. 161.

${ }^{24}$ Barry G. Wife, mother, soldier, worker: depictions of peasant women in soviet propaganda. 2016. URL: https://www.academia.edu/25142759/Wife_Mother_Soldier_Worker_Depictions_of_Peasant_Women_in _Soviet_Propaganda

25 ЦДАГО України. Ф. 1. Оп. 20. Спр.1563. Арк.45.

26 Ibid. Арк. 98.

27 Ibid. Арк. 46.

28 Ibid. Арк. 46зв- 47.
} 
Незважаючи на кадровий голод, відсутність соціальної підтримки на селі, більшовики намагалися опанувати своїм впливом якомога ширший сектор повсякденного життя місцевого населення. Так, паралельно з процесом формування організаційної структури жінвідділів у губернії, керівництво Волгубжінвідділу ініціювало передачу під їхній контроль та опіку «закладів Охматдиту, оскільки до того часу вони управлялися недосвідченими безпартійними, а в деяких випадках навіть нелояльними елементами» 29 . Це, на думку чиновників, стало причиною фіаско розгортання на Волині кампанії з відкриття ясел для дітей. Очевидно, що ситуація не покращилася зі зміною кураторів цього процесу, однак, більшовикам, в особі жінвідділів, важливо було задекларувати своє піклування проблемою охорони життя і здоров'я дітей.

У зв’язку з критичною ситуацією в питанні забезпечення жінвідділів професійними кадрами та фактичною відсутністю таких на місцях, особливо в селі, у липні 1922 р. Волгубжінвідділ ініціював проведення своєрідних курсів підготовки волосних організаторів роботи з жінками. Службовцям Волинського губжінвідділу настійно рекомендувалося «роботу серед селянок проводити через Робземліс, радгоспи і промисловість, які прикріпляють свого працівника до відповідних жінвідділів і звітують перед ними» 30 . Головне завдання цих агітаторів від жіночих відділів полягало у тому, щоб вести політико-просвітницьку роботу на селі шляхом організації недільників, роз'яснення селянам основних положень нової економічної політики радянської влади, програми більшовицької партії тощо. Однак, коли активісти намагалися розгорнути діяльність у волинських селах, несподівано вони зіткнулися з проблемою налагодження комунікації із місцевим населенням. Керівництво Волгубжінвідділу змушене було визнати, що в його штаті відсутні працівники, «які володіють українською мовою і знають підхід до селянських мас»31.

Вихід із ситуації місцеве керівництво бачило в тому, щоб, по-перше, «комуністичні осередки в селі виділяли осередкових організаторів для роботи серед жінок, які двічі на місяць мали звітувати перед губжінвідділом про зроблену роботу і отримувати подальші інструкції». Інша форма роботи полягала у «випуску для Волині щотижневої сторінки для робітниць і селянок, в якій будуть висвітлюватися питання: передвиборча кампанія делегаток; допомога голодуючим; завдання профспілок; боротьба з проституцією тощо»32. Однак, судячи з офіційної доповіді керівниці Волгубжінвідділу від 1 жовтня 1922 р., запровадження такої практики виявилося неефективним. Тому, за рішенням губжінвідділу такі «сторінки в газетах «Селянська біднота», «Волинський пролетарій» і також «Червона Волинь» рекомендувалося відмінити, а інформацію розміщувати в загальному порядку в друці»33. Аргумент на користь відміни такої сторінки видається не дуже переконливим - «Губжінвідділ не отримує інформації з центральних газет, тому не має можливості брати участь в пресі в силу своєї необізнаності про міжнародне становище»34. Тому позиція очільниці регіонального жінвідділу з цього питання була піддана гострій критиці з боку республіканського керівництва.

\footnotetext{
29 Ibid. Арк. 48.

* Робземліс - у 1920-х рр. профспілка працівників земельного і лісового господарства, яка позиціонувала себе захисником бідних і пригноблених.

30 ЦДАГО України. Ф. 1. Оп. 20. Спр. 1563. Арк. 98.

31 Ibid. Арк. 443в.

32 Ibid. Арк. 443в.

33 Ibid. Арк. 59.

34 Ibid. Арк. 61зв.
} 
Загалом інформаційні повідомлення про діяльність місцевих активісток періодично з'являлися на сторінках газети «Радянська Волинь» під рубрикою «По селах Волині». Тематика статей була різноманітною: як просвітницького, так і інформаційного характеру. Жіночій аудиторії роз'яснювали права й обов'язки подружжя, акцентуючи увагу на тому, яким чином жінка може захистити інтереси свої і дітей у разі розлучення, які зобов’язання перед сім'єю має чоловік («Які права має селянка» 35 ; «Завдання дальнішого визволення жінки в Радянському Союзі» 36 тощо); популяризували досвід суспільно-політичної діяльності окремих жінокактивісток, особливо молодих дівчат («Комсомолка Ніна», «Ударниця соціалістичних ланів» 37 тощо); у доступній формі пропагували лікнепи як шлях до подолання безграмотності («Селянко, йди до хати-читальні» 38 тощо). Усі ці публікації об’єднувала ідея звеличення ролі радянської влади, більшовицької партії у процесі визволення радянської жінки з-під сімейного та куркульського гніту, залучення їі до громадсько-політичного життя (звичайно в рамках марксистсько-ленінської ідеологічної доктрини) та господарської діяльності поза межами свого господарства. Особлива увага зверталася на роботу жінвідділів і жінделегаток, з якими селянка могла радитися й у кого могла просити допомоги чи поради.

Більшовицька пропаганда зображала жінок активними провідниками ленінських ідей на селі, «будівничими нового суспільства»39. Сторінки місцевих Волинських газет були наповнені статтями на «жіночу» тематику, автори яких, або писали про суспільні ініціативи жінделегаток, членкинь жінвідділів, або ж закликали селянок до громадсько-політичної активності, посилаючись на успіхи у цій царині їхніх товаришок робітниць. Для прикладу, в одному з номерів газети «Радянська Волинь» під рубрикою «По селах Волині» вміщено замітку про збори жінделгаток у селі Олевськ, на яких обговорюється питання про представництво жінок у Комітеті незаможних селян (далі - КНС) та відкриття ясел. 3 одного боку, автор пише про зростання зацікавленості жінок у громадсько-політичні роботі (на збори прийшли не тільки жінделегатки, але й «багато інших жінок»), а з іншого, він скептично ставиться до факту їх реальної участі у ній. Роль жінок зводиться до того, щоб «дивитись за правлінням, бо часом чоловіки крутять в інший бік»40. Новостворені інституції в рамках реалізації гендерної політики, радянською пропагандою трактувалися як своєрідні провідники «пригніченої» жінки зі стану особистої та класової залежності до світлого «радянського» майбутнього.

За відсутності широкої соціальної підтримки на селі у період свого утвердження у волинському регіоні, більшовики розглядали жінок як своїх потенційних союзників у боротьбі за владу. На початку 1920-х років місцеві партійні активісти спрямовували свою діяльність на мобілізацію жінок у напрямку збору коштів і продуктів харчування, щоб «нагодувати місто, вдягнути і взути Червону армію, яка стоїть на захисті революції, <..> спонукати дезертирів повернутися в лави Червоної армії» ${ }^{41}$. Більшовицькі пропагандисти апелювали до почуттів матерів, дочок, сестер,

\footnotetext{
35 Радянська Волинь. 1925. 15 листопада.

36 Радянська Волинь. 1925. 8 березня.

37 Радянська Волинь. 1925. 29 травня.

38 Радянська Волинь. 1925. 8 березня.

39 Непіпенко Л. Гендерна ідеологія та гендерна політика... С. 120.

40 Радянська Волинь. 1925. 22 березня.

41 ЦДАГО України. Ф. 1. Оп. 20. Спр. 349. Арк. 150.
} 
чиї родичі або відмовлялися повертатись на солдатські службу, або перебували у лавах українських повстанських загонів, закликаючи їх вплинути на своїх чоловіків, аби ті змінили негативне ставлення до радянської влади.

У період голоду 1922 р. селянки виступали окремим об’єктом більшовицької пропаганди. 3 метою посилення свого впливу на місцях і персоніфікації відповідальності за результати діяльності у цьому напрямку, в окремих інструктивних матеріалах партійних комітетів наказувалося провести вибори десятихатниць, які мали проводити організаційну роботу в селах. Держава визнавала свою неспроможність належним чином «утримувати такі заклади як соцзабез, наросвіта і відділи охорони здоров'я» ${ }^{2}$, тому частину відповідальності за підтримку найбільш нужденних категорій населення - вдів, сиріт, родин червоноармійців було перекладено на жінвідділи та жінделегаток. Серед найнагальніших стояло завдання створення комітетів взаємодопомоги, де б акумулювалися зібрані жінками фінансові та матеріальні пожертви.

Волинський губжінвідділ час від часу ініціював проведення в губернії різного роду кампаній зі збору коштів не тільки для голодуючих мешканців Волині, але й робітників інших регіонів радянської України. Так, у період з травня по грудень 1922 р. було проведено «Тиждень допомоги шахтареві. У кампанії взяли участь більше 200-х делегаток, було проведено збір коштів та пожертв. 31 червня силами делегаток розпочалася кампанія голодуючій дитині. Означені кампанії перерахували на Донбас близько двох мільярдів рублів»43.

1922 р. увійшов також в історію як початок розгортання масштабного антицерковного терору та кампанії з вилучення церковного майна нібито на користь голодуючим. Активними учасниками цих акцій виступали й місцеві жінкиактивістки, які своїм прикладом мали надихати селянок «на боротьбу з релігійними пережитками»44. Слід зауважити, що такого роду агітаційно-пропагандистська робота буда важливою складовою діяльності жіночих відділів. Крім безпосередньої участі жінок у масових акціях антирелігійного характеру, проти місцевого «куркульського елементу» тощо, партійні куратори вишукували інші, більш дієві форми пропаганди. Для прикладу, гарним агітаційним матеріалом вважалися добре поставлені імпровізовані суди. Жінвідділи залучали жінок до активної участі в такого роду дійствах. Тематика таких судових засідань вирізнялася різноманітністю: «“Суд над неграмотністю жінок”, “Суд над дезертиром праці”, “Суд над проституцією”, “Суд над сифилітичкою”. Рекомендувалися санітарні суди з тим, щоб підняти культурний рівень і гігієну» 45 .

Поза сумнівом такі «судові засідання» за участі жінок мали величезне просвітницьке та виховне значення. 3 одного боку, вони знайомили неграмотних (у масі своїй) жінок з основами правових норм і законів, а з іншого - сприяли вихованню негативного ставлення до проявів аномальної поведінки. Однак позитивний потенціал цих заходів нівелювався на тлі агресивно войовничої антицерковної політики радянської влади. Адже традиційно саме церква на селі виступала у ролі хранителя християнської моралі, сприяла вихованню молодого покоління на ії̈ цінностях. Переслідування церковнослужителів, руйнування та пограбування храмів на

\footnotetext{
42 ЦДАГО України. Ф. 1. Оп. 20. Спр. 1557. Арк. 145.

${ }^{43}$ ЦДАГО України. Ф. 1. Оп. 20. Спр. 1563. Арк. 47.

44 ЦДАГО України. Ф. 1. Оп. 20. Спр. 1557. Арк. 145.

45 ЦДАГО України. Ф. 1. Оп. 20. Спр. 1563. Арк. 31зв.
} 
тлі насильницького зламу устоїв сільського життя, призвело до поглиблення системної кризи у волинському селі.

В означений нами період зусиллями жінвідділів апропрійовувалася ленінська теза про класову боротьбу на селі, що, на нашу думку, так само детермінувало соціальний конфлікт і не сприяло консолідації сільського соціуму. На практиці ця політика реалізовувалося шляхом «встановлення певних категорій селянок: куркуль, середняк, незаможник, батрак і сільськогосподарський пролетаріат». Основним об’єктом впливу з боку українських жінвідділів визначалися «сільськогосподарські робітниці батрачки і незаможниці. Важливе завдання для партії полягало у розширенні впливу на селянку середнячку»46. В офіційних партійних документах жінвідділам рекомендувалося залучати найбідніших селянок до агітаційнопропагандистської роботи на селі, «до участі в зборах незаможних селян для обговорення питань сільського господарства» ${ }^{7}$, звертати на них особливу увагу під час «виборів жінделегаток, організації політгуртків сільськогосподарських знань» ${ }^{48}$. Однак, на відміну від більш заможних середнячок, батрачки не користувалися авторитетом серед земляків і в масі своїй потенційно не були готові стати місцевими лідерами. Тому губернське керівництво змушене було підбирати кадри на заміщення вакантних посад волосних жінорганізаторів серед нечисленних представників сільської інтелігенції, або ж так званих «середняків». Незважаючи на очевидний кадровий голод, більшовики не відмовлялися від використання тактики класової боротьби на селі шляхом нагнітання атмосфери ненависті, соціального протистояння. Поза офіційні рамки суспільно-політичного життя на місцях були поставлені категорії заможних селян, у тому числі - й жінки. Ця тенденція посилювалася з кожним роком, що призвело до штучної маргіналізації цілої верстви населення, переведення їх у категорію «ворогів народу, «позбавленців», «шкідників» і тому подібне.

Попри всі зусилля більшовицької партії ідея розгортання жіночого руху на підтримку соціально-економічних і політичних перетворень радянської влади на селі не мала очікуваного успіху. Селянки у масі своїй залишалися вкрай пасивними та консервативними у своєму баченні майбутніх перспектив соціалістичного ладу. Опосередкованим свідченням цього є факт існування тотальної кадрової кризи в розрізі підбору організаторок жіночого руху на місцях, про що йдеться у багатьох документах того часу. Зокрема, керівник Волгубжінвідділу в одному зі своїх звітів наголошує на «гострій проблемі в кваліфікованих жінкадрах, з однієї сторони, і матеріального забезпечення, з іншої» ${ }^{49}$, а влітку 1922 р. вона заявила, що «враховуючи волинські умови як чисто селянської губернії, центром роботи повинна бути робота на селі. Губжінвідділ не в змозі проводити цю роботи без допомоги сільських ланок. А сільські ланки по своєму політичному розвитку надзвичайно слабкі»50. Найпростіший вихід з цієї ситуації партійні чиновники бачили у залученні для роботи в селах робітниць з промислових українських центрів. Паралельно 3 цим, по-перше, налагоджувалася робота з організації спеціальних курсів для підготовки жіночих організаторів з числа місцевих активісток, по-друге, велась агіта-

\footnotetext{
46 ЦДАГО України. Ф. 1. Оп. 20. Спр. 1557. Арк. 137.

47 ЦДАГО України. Ф. 1. Оп. 20. Спр. 1554. Арк. 75.

48 ЦДАГО України. Ф. 1. Оп. 20. Спр. 1557. Арк. 117.

49 ЦДАГО України. Ф. 1. Оп. 20. Спр. 1563. Арк. 47.

50 Ibid. Арк. 53.
} 
ційна робота зі вступу селянок до лав більшовицької партії, а молодих дівчат комсомолу.

Таким чином, важливою складовою процесу радянізації українських регіонів виступала кампанія зі створення у структурі більшовицької партії спеціальної організаційного підрозділу - жінвідділу, який відповідав за ведення роботи серед жіночого населення. Від самого початку вектор і моделі діяльності цього органу визначалися комуністичною партією. Спосіб підбору та рекрутизації кадрів у регіональні жінвідділи, окреслення основних завдань порядку денного їх діяльності свідчать про відсутність масової підтримки цього руху у середовищі сільського жіноцтва, зокрема Волинського регіону. Можна стверджувати, що емансипаційна політика розглядалася радянською владою як інтегральна складова загального процесу радянізації. Вона була нерозривно пов'язана з вирішенням завдань, які сприяли її утвердженню на селі: проведення агітаційно-пропагандистської роботи, організація посівної та хлібозаготівельних кампаній, створення комітетів незаможних селян, опіка над соціально незахищеними верствами населення тощо. Діяльність жінвідділів не сприяла консолідації сільського соціуму. Швидше навпаки, ідучи у фарватері політики більшовицької партії, сільські активістки організовували свою роботу на засадах класового антагонізму. Попри обмеженість у Волинському регіоні джерел кадрового поповнення жінвідділів із середовища місцевого населення, від початку їх організаційного оформлення головний акцент ставився на роботу з найбіднішими та середніми верствами українського села. Жінки із заможних селянських сімей, родин священнослужителів та інших службовців «колишнього царського режиму» апріорі позбавлялися права обіймати посади в жіночих організаціях.

\section{REFERENCES}

Aivazova, S. (1998). Russkie zhenshchiny v labirinte ravnopraviia (Ocherki politicheskoi teorii i istorii Dokumentalnye materialy) [Russian women in the labyrinth of equality (Essays on political theory and history. Documentary materials)]. Moskva: RIK Rusanova [in Russian].

Barry, G. (2016). Wife, mother, soldier, worker: depictions of peasant women in soviet propaganda. Retrieved from https://www.academia.edu/25142759/Wife_Mother_Soldier_Worker_Depictions_of_Peasant_Wome n_in_Soviet_Propaganda [in English].

Baturenko, S. (2019). Marksistskii feminizm teoreticheskii proekt genezis i opyt prakticheskoi realizatsii v XX v. [Marxist feminism as theoretical project, genesis and experience of implementationin the XX century]. Vestnik Moskovskogo Universiteta, Ser. 18: Sotsiologiia i politologiia, T. 25, 11-129 [in Russian].

Clements Barbara Evans (1997). Bolshevik Women. New York and Cambridge, England: Cambridge University Press [in English].

Jarska, N.A. (2018). Patriarchal marriage? The women's movement and the communist party in Poland (1945-1989). Kwartalnik Historyczny, Vol. CXXV, Eng.-Language Edition, 2, 7-37 [in English].

Khartmann Khaidi (2016). Neschastlivyi brak marksizma s feminizmom put $k$ bolee progressivnomu soiuzu [The Unhappy marriage of Marxism with Feminism: the way to a more progressive alliance]. Moskva: Svobodnoe marksistskoe izdatelstvo. Retrieved from https://fmbooks.files.wordpress.com/2016/10/hartmann-fin-fin.pdf [in Russian].

Labur, 0. (2014). Spohady predstavnyts zhinviddiliv yak dzherelo vyvchennia radianskoi polityky «zhinochoho rozkripachennia» v Ukraini 1920-kh rr. [Memoirs of Zhynviddil's Members as Source to Research Study of the «Women's Liberation» in Soviet Ukraine in 1920's]. Storinky istorii, 37, 117-127 [in Ukrainian].

Nepipenko, L. (2019). Henderna ideolohiia ta henderna polityka v radianskii politychnii kulturi Ukrainy periodu NEPu [Gender ideology and gender policy in the Soviet political culture of Ukraine during the times of the New Economic Policy]. Hileia: naukovyi visnyk, 145(1), 116-123 [in Ukrainian]. 
Oliinyk, N.Yu. (2015). Emansypatsiia zhinok po-radiansky: osoblyvosti ta naslidky [Emancipation of women in the soviet era: features and consequences]. Hrani, 6, 144-151 [in Ukrainian].

Pushkareva, N. (2012). Gendernaia sistema Sovetskoi Rossii i sudby rossiianok [The gender system of Soviet Russia and the fate of Russian women]. Novoe literaturnoe obozrenie, 17, 8-23 [in Russian].

Simonton, Deborah (2007). Women workers, working women. The Routledge History of Women in Europe since 1700. London and New York, 134-176 [in English].

Starodubets, G. (2020). Osnovni vektory hromadsko-politychnoi diialnosti silskoho zhinotstva Volyni naprykintsi 1920-kh - na pochatku 1930-kh rokiv [The main vectors of socio-political activity of rural women in Volyn in the late 1920s and early 1930s]. Naukovi zapysky Vinnytskoho derzhavnoho pedahohichnoho universytetu im. M. Kotsiubynskoho. Seriia: Istoriia, 32, 9-17 [in Ukrainian].

Voronina, M. (2017). Bilshovytskyi emansypatsiinyi eksperyment u 1920-kh rokakh [The Bolshevik emancipation experiment in the 1920s]. In Ukrainski zhinky u hornyli modernizatsii. Kharkiv, pp. 106130 [in Ukrainian].

Voronina, O.A. (2003). Feminizm i gendernoe ravenstvo [Feminism and Gender Equality]. Moskva: Editorial URSS [in Russian].

Zemziulina, N. (2013). Ideolohichni ta pravovi mekhanizmy formuvannia hendernoho parytetu v SRSR [Ideological and legal mechanisms for the formation of gender parity in the USSR]. Visnyk Cherkaskoho universytetu. Seriia: Istorychni nauky, 29, 132-138 [in Ukrainian].

\section{Galyna Starodubets}

(Zhytomyr Ivan Franko State University, Zhytomyr, Ukraine)

e-mail: starodubec@gmail.com

ORCID: https://orcid.org/0000-0003-2005-771X

\section{The main vectors and agents of socio-political mobilization of rural women of Volyn in the first years of establishment of Soviet Power}

The October coup of 1917 in the Russian Empire determined the establishing of new standards of gender policy of the Soviet State by the Bolshevik Party. Their introduction took place in parallel with the process of Sovietization of certain territories of the former empire. It had both common and distinctive features, which to some extend manifested themselves in particular regions. The subject of our study is the women's movement in Volyn in the first half of the 1920s. The location of the region on the border, its national diversity, mainly the agrarian nature of the economic system were reflected in the regional specifics of the women's movement.

The objective of our article is to reveal the determinants of political and social mobilization of peasant women during the first decade of the Soviet government on the example of the Volyn region; to identify the main agents of influence on the process of organizing the women's movement in the villages and establishment of its content and forms.

The methodological basis of the study is the principles of scientificity, historicism, determinism, a combination of systemic and regional approaches, authorial objectivity. A set of general scientific and specifically historical (historical-genetic, historical-typological, historical-systemic) methods was used to solve the set tasks. The scientific novelty is that for the first time in the historiography of the Ukrainian women's movement the topic of involvement of rural women in the process of Sovietization of Volyn in the first half of the 1920s was clarified, as well as the policy of Bolshevik's power of using women as an important instrument of imposing the soviet power in the region was disclosed basing on previously unknown archival documents. The controllability of the process of activation of women by party structures is shown.

Conclusions. It can be stated that the emancipation policy was considered by the Soviet authorities as an integral part of the overall process of Sovietization. It was tightly linked with solving the tasks that contributed to its establishment in the village: conducting propaganda work, organizing sowing and harvesting campaigns, creating the committees of poor peasants, care for the socially vulnerable, etc. The activities of women's departments did not contribute 
to the consolidation of rural society. On the contrary, following in the footsteps of the Bolshevik Party's policy, rural activists organized their work on the basis of class antagonism.

Keywords: Bolsheviks, women's departments, Soviet power, class enemies, women, peasants 